\title{
Life in Conflict: Prevelance of Somatoform Disorders among the Youth of Militancy Affected Areas
}

\author{
Muntazir Maqbool Kermane* \\ Department of Education Government of Jammu And Kashmir, India
}

Submission: August 14, 2018; Published: September 05, 2018

*Corresponding author: Dr Muntazir Maqbool Kermane, Department of Education Government of Jammu And Kashmir, India, Tel: 919697382295; Email: peerzadamuntazir@gmail.com

\begin{abstract}
War has a heart pounding impact on everyone, especially to those who are experiencing it up-close. The effect is at most to those who fought in the war and their families and relatives. War and its related activities, as also in the case of militancy in J\&K, which the present study centers on, causes separation of family members, death, injuries, sickness, fight, alarm, panic, worry and so on. This gives rise to anxiousness and feeling of apprehension. The present study was confined to assess the psychological construct of Somatoform disorders among the militancy affected youth of J\&K state. 300 youth within the age range of 20-35 were taken as the subjects. Data analysis was done by SPSS 20; two way analysis of variance followed by Turkeys HSD was used. Results revealed that the youth of militancy affected areas have more somatoform disorders in comparison to the youth of unaffected areas. The directly affected youth are highly affected in comparison to indirectly affected and unaffected youth of militancy affected areas. No significant difference was found in gender in all the three categories.
\end{abstract}

\section{Introduction}

Jammu and Kashmir state the crown of Indian map is situated between $32017 \mathrm{~N}$ and $360582 \mathrm{~N}$ latitude, and $730262 \mathrm{E}$ and 800 $302 \mathrm{E}$ longitude, constitutes the northern most state in India. The altitude varies from 1000 to 28250 feet above the sea level. It is in the north part of the Indian subcontinent and is surrounded by snow-capped high mountain chains of Himalaya and Karakoram. The State of Jammu and Kashmir is situated in the northeast by the Uygur Autonomous Region of Sinkiang and Tibet (Peoples Republic of China); it is bordered by the Indian states of Himachal Pradesh and Punjab in the South, on the northwest by Afghanistan and the west by Pakistan Rehman [1]. By way of its excellent geographical location and richness of its renewable resources, especially water, the State has significant political, strategic and economic importance. It has a total area of 222,236 sq. Km (78,114 sq. Km under the occupation of Pakistan, 37,555 sq. Km under China, and another 5,180 sq. Km handed over to China by Pakistan). The erstwhile princely state was administratively divided into Jammu, Kashmir, Ladakh, and Gilgit. In 1949, it was bifurcated the Indian part consists of Jammu, Kashmir, and Ladakh. The Muzaffarabad area and Northern Areas are under de facto Pakistan administration. lso, besides China controls the trans-Karakoram Shaksgam Valley and the adjacent region, which Pakistan unilaterally ceded to it in 1963 as part of a boundary settlement, and also Aksaichin and a strip of Western Ladakh, into which it intruded and then militarily occupied in 1962 (Verghese 2007) (Singh 2011). The overall population of 12.5 Million is divided between Jammu (43\%) and Kashmir (55\%). Kashmir has a Muslim majority of 97\%, which speaks Kashmiri (census 2011).

\section{Militancy in Kashmir Causes and Rise}

"History has seen such times when the crime was committed in a moment, but the punishment was suffered by centuries". (Shiekh Mohammad Abdullah 1981) In 1947, Kashmir-along with 561 princely states - was independent as long as it recognized the supremacy of the British Empire. The rulers of all these states were autonomous except in the most crucial areas; defense, foreign affairs and communication. During Partition, Lord Mountbatten added two qualifications to his edict regarding the princely states. Firstly the geographies of each state should be adhered to; secondly, all areas that were predominantly Muslim would join the newly formed Pakistan; while the non-Muslim States should grow to be part of India Ganguly [2]. Under the terms of the Indian Independence Act, none of the Princely States would be permitted to declare independence. Kashmir was one of the few Princely States that due to its geographical location could have tied either India or Pakistan Hewitt [3]. Despite this, it was commonly assumed that Kashmir would accede to Pakistan as it had an $80 \%$ Muslim population Rees [4]. It is important to discuss here why the two complex factors exacerbated the dispute over the Kashmir. A predominantly Muslim Kashmir holds gigantic symbolic value for India as the State is the test of its secular ideology. For Pakistan, Kashmir encompasses the nation's Islamic identity, the State of Kashmir being the missing part. However, 
India can unwell afford to be weak on domestic insurgencies (they also have secessionist movements in Punjab and Assam): allowing Kashmir to become independent would set a guide for state secession (Kapur and Narang, 2001).

After gaining the independence from the British rule, India was partitioned into two nations of India and Pakistan. The princely state of Jammu \& Kashmir became an independent nation on August 14-15th 1947 with an understanding that it would soon choose its future. India wanted J\&K to be its part while being the dominance of Muslims Pakistan wanted Kashmir to be the part of his nation. October 22th, 1947 was the most unfortunate time in the history of Kashmir when the impatient Pakistan invaded Kashmir from the north with the tribesmen and an army of soldiers armed with modern weapons. The invaders brutal sackings of towns and mass killings created the mass hysteria among the people of Kashmir. When Hari Sings unprepared Dogra troops fell helpless in front of attackers he sent Shiekh Abdullah and his representatives to Delhi to seek India's help. On October $26^{\text {th }}, 1947$ Maharaja Hari Singh signed the instrument of accession to India. Unlike the other princely states, the case of Jammu and Kashmir was "accession" not "merger" Bose S [5,6]. From the beginning of 1988, the situation in the state of Jammu and Kashmir starts deteriorating with rapid speed. Militancy flourished its grounds in the beautiful valley of Kashmir influencing each and every individual of the society resulting in unending violence and ruining of the Psychological health of the people of Valley. This journey was supposed to begin from the ballot box, but unfortunately, they were left with only one option that is the bullet. Consequently, the Valley was overtaken by militancy, strikes, bomb blasts, firing, etc. From 1989 onwards the situation in the valley deteriorated from bad to worse with bloody clashes between Indian Paramilitary troops and the militants became the daily affairs of Kashmir. Militancy had changed the whole State. In fact, hardly any aspect of life is there which has not been affected by this. Long turmoil years of violence and bloodshed had brought radical, socio-economic, religious and behavioral changes in the society.

\section{Description of the Variables}

\section{Militancy}

Militant is virtually a euphemism for "terrorist", more contentious and potentially subject to action for libel. News papers, magazines and other information source may view 'militant' as a neutral term, whereas 'Terrorist' conventionally indicates disapproval of the behavior of the individual or organization so labeled, regardless of the motivations for such behavior Jackson, Gunning, Smyth [7]; Mudassir \& Khan [8]. The mass media often uses the term 'militant' in the context of terrorism (Sanders, 1990). By common consent, militancy has emerged as the defining threat of the $21^{\text {st }}$ century. The term militancy state "colloquially" refers to a state which holds an aggressive posture in support of an ideology of cause. In general usage, a militant person is a confrontational person, regardless of the use of physical violence or pacifistic methods. In recent years, the emergence of militancy has become burning issue. The headlines of newspapers, news bulletins or television and radio broadcast tell us how people are short dead, injured or kidnapped, planes are hijacked with many passengers, banks are looted Shiekh [9].

\section{The Contemporary Definition of Militancy}

The term militant was derived during French revolution in $15^{\text {th }}$ century. Militancy is based on the Latin verb "military" meaning, "to serve as a solider". The term militant can describe as those who aggressively and violently promote political philosophy in the name of movement (and sometimes have an extreme solution for their goals). The militant view sometimes constitutes an extremist position sheikh [9].

a. Youth: The meaning of youth, and the way society regards youth, varies across the time and space as well as within societies. In particular, youth has an important gender dimension: boys and girls might experience being young in a considerably different way. Hence, in addition to being defined chronologically (as a period of age, between certain ages), youth is also defined functionally as a period of transaction from childhood to adulthood, marked by rituals or physical changes, as well as culturally (pertaining to the role that individual play in a given social context) UNDP [10]. National youth development policy (2001) defined youth as people aged from 18-35 years.

b. Directly Affected: Here refers to the youth which are greatly affected. They witness the major problems like death of family member/s, rape, destruction of personal property, torture etc by militancy.

c. Indirectly Affected: Here refers to the youth who resides in militancy affected areas and have witnessed such major problems in their neighborhood or surroundings but not in their own families.

d. Unaffected: Here refers to the youth who are the residents of areas of Jammu and Kashmir State where they are not affected by the militancy (Jammu and its allied areas).

\section{Somatoform Disorders (SOM)}

Somatoform disorders disorder is a long-term (chronic) condition in which a person has physical symptoms that involve more than one part of the body, but no physical cause can be found. The pain and other symptoms people with this disorder feel are real, and are not created or faked on purpose (malingering). Patients with somatoform disorders disorder also show high levels of worry, anxiety, and increased reactions in response to physical symptoms Burton et al. [11]. Somatoform disorders is a condition in which the patient experiences unexplained medical symptoms and is sometimes called "functional somatic complaints". Somatoform disorders refers to the development of somatic symptoms for which no organic cause is found (Escalana et al 2004, North et al 2004) such symptom are called somatoform symptoms. 
Hypothesis-1: There would be a significant difference in Somatoform disorders of directly affected, indirectly affected and unaffected youth of militancy affected areas.

Hypothesis-2: There would be a significant difference in Somatoform disorders of male and female youth of directly affected, indirectly affected and unaffected youth of militancy affected areas.

Samplez: The sample of the present study consisted of 300 youth of Jammu and Kashmir state $(\mathrm{N}=300)$ whose age range were between 20-35 years. For the present study the samples were collected through the quota sampling method. The sample was divided into three equal categories of 100 samples $(n=100)$, i.e. 100 directly affected, 100 indirectly affected and 100 unaffected youth. Each category was further divided into both genders i.e. males and females of equal numbers.

Sample Design: The samples were taken in three phases. In the first phase the samples of directly affected was taken from the Kashmir valley mostly from the north, central and north east regions of the valley. In the second phase the samples for the indirectly affected youth was taken. The required numbers of samples were taken from the Kashmir valley with majority of the cases from Baramulla, Bandipora, Kupwara, Srinagar, Budgam, Anantanag and Ganderbal districts of valley Kashmir. In the third phase the samples were taken for the third category i.e. unaffected youth. The required samples were taken from the Jammu region of the J\&K state. The reason for taking the samples from this region is that the majority of the regions of Jammu are militancy free. Therefore the youths of this region are not affected by militancy.

\section{Results}

\section{Data Analysis for Somatoform Disorders}

\section{Analysis of Variances for Somatoform Disorders}

Tables 1-3 Somatoform disorders scores were subjected to univariate analysis of variance ( $2 \times 3$ ) having two levels of gender (male, female) and three levels of category (Directly affected, indirectly affected and Unaffected). Then the scores were subjected to Post Hoc ANOVA (Turkey's HSD). The results are tabulated as below:

Table 1: Descriptive statistics for Somatoform disorders.

\begin{tabular}{|c|c|c|c|c|}
\hline \multicolumn{5}{|c|}{ Mean \& SD scores of Categories } \\
\hline \multirow{2}{*}{ Gender } & $\begin{array}{c}\text { Directly } \\
\text { affected }\end{array}$ & $\begin{array}{c}\text { Indirectly } \\
\text { affected }\end{array}$ & Unaffected & Total \\
\hline \multirow{2}{*}{ Male } & $\mathbf{( n = 5 0 )}$ & $\mathbf{( n = 5 0 )}$ & $\mathbf{( n = 5 0 )}$ & $\mathbf{( N = 1 5 0 )}$ \\
\hline \multirow{2}{*}{ Female } & 67.02 & 63.38 & 56.66 & 62.35 \\
& -6.57 & -6.562 & -7.56 & -8.107 \\
\hline \multirow{2}{*}{ Total } & 67.82 & 60.84 & 55.74 & 61.47 \\
& -6.895 & -8.46 & -8.101 & -9.243 \\
\hline
\end{tabular}

Standard deviation (SD) appears in parenthesis below mean.
Table 2:Summary of 2 X 3 ANOVA (Gender X Category) for Somatoform disorders.

Summarizes the results of two-way analysis of variance for somatoform disorders scores. The main effects of gender yielded on $F$ ratio of, $F$ $(1,294)=1.078, P>0.05$ which was found to be insignificant. The main effects of category was found to be significant, $F(2,294)=57.591$, $P<0.05$. The interaction effect of Gender and Category was also found to be insignificant, $F(2,294)=1.275, P>0.05$. Thus, indicating that category causes significant variation in somatoform disorders scores while as neither Gender nor interaction of gender and category causes significant variation in Somatoform disorders scores.

\begin{tabular}{|c|c|c|c|c|c|}
\hline Source & SS & Df & MS & F & P \\
\hline Gender & 58.963 & 1 & 58.963 & 1.078 & .300 \\
\hline Category & 6300.420 & 2 & 3150.210 & 57.591 & $.000^{*}$ \\
\hline $\begin{array}{c}\text { Gender } \\
\text { *Category }\end{array}$ & 139.487 & 2 & 69.743 & 1.275 & .281 \\
\hline Error & 16081.700 & 294 & 54.700 & & \\
\hline Total & 1172435.000 & 300 & & & \\
\hline
\end{tabular}

* = Significant at 0.05 level: F.95 $(2,294)$.

Table 3:Significance of mean difference in somatoform disorders between directly affected, indirectly affected, and unaffected youth. Post Hoc test, multiple comparisons (Turkey HSD).

\begin{tabular}{|c|c|c|c|c|}
\hline $\begin{array}{c}\text { Category of } \\
\text { subjects (I) }\end{array}$ & $\begin{array}{c}\text { Category of } \\
\text { subjects (j) }\end{array}$ & $\begin{array}{c}\text { Mean } \\
\text { difference } \\
\text { (I-J) }\end{array}$ & $\begin{array}{c}\text { Standard } \\
\text { Error }\end{array}$ & Sig. \\
\hline \multirow{2}{*}{$\begin{array}{c}\text { Directly } \\
\text { affected }\end{array}$} & Indirectly affected & $5.31^{*}$ & 1.046 & .000 \\
\cline { 2 - 5 } & Unaffected & $11.22^{*}$ & 1.046 & .000 \\
\hline \multirow{2}{*}{$\begin{array}{c}\text { Indirectly } \\
\text { affected }\end{array}$} & Directly affected & $-5.31^{*}$ & 1.046 & .000 \\
\cline { 2 - 5 } & Unaffected & $5.91^{*}$ & 1.046 & .000 \\
\hline \multirow{2}{*}{ Unaffected } & Directly affected & $-11.22^{*}$ & 1.046 & .000 \\
\cline { 2 - 5 } & Indirectly affected & $-5.91^{*}$ & 1.046 & .000 \\
\hline
\end{tabular}

Table 3 reveals that the mean difference $(I-J)=5.31$, standard error $=$ 1.064 in somatoform disorders between directly affected and indirectly affected youth is significant $P<0.05$. Mean difference $(I-J)=11.22$, standard error $=1.064$ in somatoform disorders between directly affected and unaffected youth is significant at $P<0.05$. While as mean difference $(I-J)=5.91$, standard error $=1.064$ in somatoform disorders between indirectly affected and unaffected was also found significant $\mathrm{P}<0.05$.

As from the above, it is revealed that the hypothesis $\mathrm{H} 1$ "There would be a significant difference in somatoform disorders of directly affected, indirectly affected and unaffected youth of militancy-affected areas" is accepted.

The hypothesis H2 "There would be a significant difference in somatoform disorders of directly affected, indirectly affected and unaffected males and females of militancy-affected areas" is rejected. Tables 3 reveals that the mean difference $(I-J)=$ 5.31, standard error $=1.064$ in somatoform disorders between directly affected and indirectly affected youth is significant $\mathrm{P}<0.05$. Mean difference $(\mathrm{I}-\mathrm{J})=11.22$, standard error $=1.064$ in somatoform disorders between directly affected and unaffected youth is significant at $\mathrm{P}<0.05$. While as mean difference $(\mathrm{I}-\mathrm{J})=$ 5.91 , standard error $=1.064$ in somatoform disorders between indirectly affected and unaffected was also found significant $\mathrm{P}<0.05$. It is concluded from the above tables that there is a 
significant difference in the somatoform disorders among directly affected, indirectly affected and unaffected youth. The directly affected youth (Mean=67.42, SD=6.712) have more somatoform disorders symptoms than indirectly affected youth (Mean=62.11, $\mathrm{SD}=7.639$ ). While as least somatoform disorders symptoms are in the unaffected youth (Mean= 56.20, SD= 7.812). There is no significant difference in mean scores among the males and females of all the three categories (Figure 1).

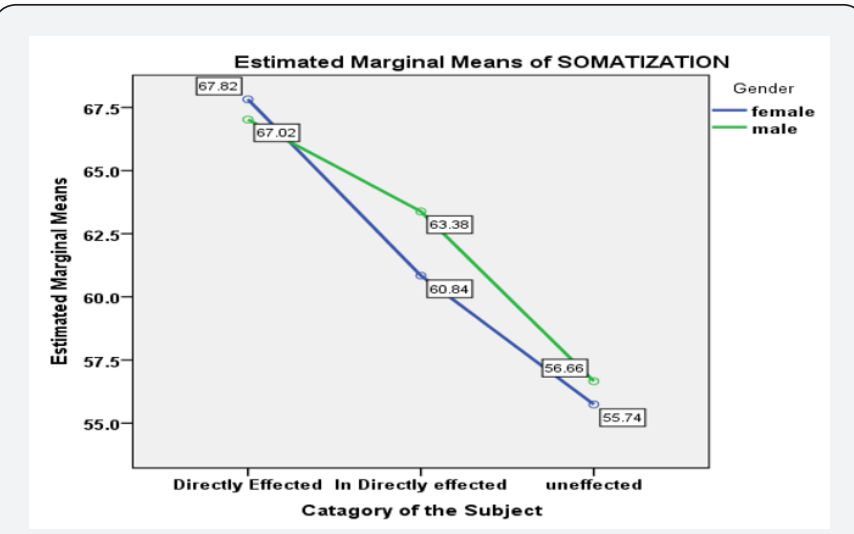

Figure 1: Profile of Somatoform disorders for gender and category.

\section{Discussion and Interpretation}

"The greatest discovery of my generation is that human beings can alter their lives by altering their attitudes of mind." William James (1842-1910). "Don't become a mere recorder of facts, but try to penetrate the mystery of their origin." Ivan Pavlov (18491936). There is an alarming increase in the mental illness due to a persistent wave of violence, political turmoil and frequent change in the social fabric countries worldwide (WHO 2001, 2005). Approximately 25 million people in the world are displaced due to violent conflict. Millions are affected by war worldwide. It resulted in the range of psychiatric disorders reported such as depression, substance and alcohol abuse, schizophrenia, bipolar disorder, and post-traumatic stress disorder Gadit [12]. The prevalence of mental illness is much greater among war-affected populations than the general population. $30-70 \%$ of people who have lived in war zones suffer from symptoms of post-traumatic stress disorder (PTSD) and depression. The continuous violence and threat to life have led a damaging effect on the psychological health of many in general Marzuk [13]. Since September 1988 when the security forces came with the first Kalashnikov in the valley, there has barely been a day when Kashmir has not been in the news. Thousands of people, militants, security personnel and innocent civilians have perished in the ongoing war of abrasion between security forces and various secessionist elements, yet platitudes apart there has been no effort to make a scientific evaluation of the feelings of those who suffer the most-the Kashmir's themselves. The people who carried on with the business of living in one of the worst trouble spots on the globe? Kashmir Valley is measured to be one of the most likely places on the earth to witness a potential breakout of major conflict at any point in time Scobell [14]. Beyond the physical effects of war, the psychological effects are of great importance. Children/adolescents are often witnesses to violent incidents, faced into separation from their families are prone to separation and families from their homes. War/insurgency creates the multitude of orphans whose needs must be addressed purposely and with sensitivity. The psychological consequences of all the above can be very stern and long lasting Pine et al. [15]. Jammu \& Kashmir is the state that has borne the maximum impact of the three wars that Pakistan has inflicted on India as well as of the painful and devastating proxy war unleashed by Pakistan in 1989. Since 1947, the state has been in the constant frown of the international media, but little is known about it both within the States of India and abroad. Kashmir, a conflict zone, has been constantly in a state of low-intensity war since last 24 years, and this leads to the increased mental health disorders. Apparently, employment and education sector major craving areas of youth are worst affected by insurgency Shoaib et al. [16].

The somatoform disorders symptoms are high among the directly affected youth as compared to indirectly and unaffected youth. The indirectly affected youth have more somatoform disorders symptoms than unaffected youth but lesser than the directly affected youth. Tables 1-3 also showed that the gender differences in somatoform disorders symptoms were not found significant. Although males report more somatoform disorders symptoms in all the categories except directly affected category where females report little bit high somatoform disorders symptoms than males. This might be attributed to the cause that the people of conflict areas live in highly stressful environment. The somatic symptoms like headaches, non-specific pains or discomfort in torso and limbs, dizziness, weakness and fatigue are central to the subjective experience and communication of distress brought by war, insurgency, militancy etc. When distress develops and continues over prolonged period, psychophysiological disorders may develop. Similar results were found by MSF (2006) in Kashmir valley the survey indicated high rates of physical complaints including headaches (23.5\%), body pains such as joint and back complaints (20.5\%) and abdominal complaints (16.9\%). It is reported that poorly placed a substantial burden on the area's health facilities, with most people saying they consult health clinics frequently (63.9\%), some even four times or more. Somatoform symptoms have consistently been linked to traumatic exposure. Traumatic victims tend to score higher on self-reports of somatic complaints as compared to controls (North et al 2004, Andreski et al 1998, Brady 1997, Mcfailane et al. [17]). Somatoform disorders may be related to other psychological consequences of trauma such as depression, anxiety, dissociation and PTSD [18].

\section{References}

1. Rehman M (1996) Divided Kashmir: Old Problems, New Opportunities for India, Pakistan, and the Kashmiri People.

2. Ganguly S (1997) The crises of Kashmir: Patients of war, Hopes of peace, Cambridge: Cambridge University press.

3. Hewith V (1997) Kashmir: the answered question. History today 47: 9. 
4. Rees P (2005) Dinning with terrorists: meetings with the world's most wanted militants London Macmillan.

5. Bose S (1997) The challenge in Kashmir, Democracy, Self- determination and just peace, New Delhi: Sage publication.

6. Bose S (2003) Kashmir roots of conflict, paths to peace, Harward: Harward University press.

7. Jackson R, Gunning J, Smyth M (2009) Critical Terrorism: A new research agenda, New York.

8. Mudassir H, Khan W (2014) Traumatic experiences of Ex- militants in Kashmir. European Academic Research ii: 6465-6467.

9. Shiekh S (2009) Psychological wellbeing, emotional intelligence and self-efficacy among militancy and non-militancy affected people in Kashmir. Jamia Milia Islamia, New Delhi, India.

10. UNDP (2006) Youth and violent, conflict: society and development in crisis: United nations development programme, USA.

11. Burton D, Pickering M, Weinberg R, Yukelson D, weigand D (2010) Competitive goal effectiveness paradox revisited. Journal of applied sport psychology 22(1): 72-86
12. Gadit AAM (2007) Mental health model: comparison between a developing country. Journal of Medicine (serial online)

13. Marzuk P (1996) Violence, crime and mental illness, how strong a link? archives of general psychiatry 53: 481-6

14. Scobell A (2001) Flashpoint Asia: The most dangerous place?. Parameters 31: 129-133.

15. Pine DS, Costello J, Masten A (2005) Trauma proximity and developmental psychopathology. Effects of war and terrorism on children. Neuropharmocology 30: 1781-1792.

16. Shoaib S, Dar M M, Bashir H (2012) psychiatric morbidity and the socio-demographic determinants of patients attempting suicide in Kashmir valley: a cross sectional study. International Journal of Health Science and Research 2(7): 45-53.

17. McGuffin P, Reich T (1994) Psychopathology and genetics. In HE Adams, PB Sutker (Eds.), comprehensive hand book of psychopathology New York: Plenum press.

18. Medicins Sans Frontiers (MSF) (2006) Kashmir violence and mental health report.

\section{Your next submission with Juniper Publishers} will reach you the below assets

- Quality Editorial service

- Swift Peer Review

- Reprints availability

- E-prints Service

- Manuscript Podcast for convenient understanding

- Global attainment for your research

- Manuscript accessibility in different formats

(Pdf, E-pub, Full Text, Audio)

- Unceasing customer service

Track the below URL for one-step submission https://juniperpublishers.com/online-submission.php 